\title{
JURISPRUDENCE
}

\section{Restriction of Liberties under the Ontario Review Board af- ter (Re) Campbell}

\author{
Lauren Barney ${ }^{1}$
}

\author{
St. Joseph's Healthcare Hamilton, Forensic Psychiatry \\ Program, Hamilton, Canada
}

In Canada, Review Boards are established under Part XX.1 of the Criminal Code of Canada. The role of these independent tribunals is to make and review dispositions and decisions concerning persons found Not Criminally Responsible on Account of Mental Disorder or Unfit to Stand Trial. Under Part XX.1, there exist certain provisions to protect the liberty interests of accused persons who remain under the authority of a provincial or territorial review board. These provisions trigger mandatory hearings before the Review Board. In (Re) Campbell, counsel for the accused argued before the Board that a transfer from one secure unit to a more secure unit required notice to the Board of a restriction of liberty and furthermore, that the delay in notification resulted in a section 7 Charter breach and that a remedy under section 24(1) of the Charter was due. The Court of Appeal dismissed the appeal, confirming the Board's decision that there was insufficient evidence regarding the accused's liberty norm before the transfer and her liberty status after the transfer to conclude that notice to the Board was required. Furthermore, the Court ruled that the transfer was the least onerous and least restrictive measure in the circumstances. The Campbell decision introduced an enhanced interpretation of the "significantly increasing the restrictions on the liberty of the accused" test by adopting a contextual approach which takes into consideration the accused's liberty status before and after the decision to restrict the accused. Once a restriction is deemed to reach that threshold, the Board must determine whether the hospital's measures were the least onerous and least restrictive in the circumstances. The Campbell decision will undoubtedly impact the way hospitals and review boards view restrictions of liberty, giving way to the potential for an increasing number of Charter cases argued on the grounds of alleged section 7 violations.

\section{Keywords}

Not Criminally Responsible, Mental Disorder,
NCRMD, Criminal Code, Restriction of Liberty, Least onerous, Least restrictive, Liberty Norm, Liberty Status, Charter

\section{Introduction}

In Canada, Review Boards (hereinafter Boards) are established under Part XX.1 of the Criminal Code of Canada (hereinafter Criminal Code). The role of these independent tribunals is to make and review dispositions and decisions concerning persons found Not Criminally Responsible on Account of Mental Disorderii (NCRMD) or Unfit to Stand Trialiii (UST). The Board panel is composed of no fewer than five members with differing areas of expertise, including an alternate-chairperson who is a lawyer of at least 10 years' experience or a judge or a retired judge ${ }^{\text {iv }}$, a psychiatrist, a psychologist, a legal member, and a public member." Decisions of the Board may be appealed to the appellate court where the decision was made ${ }^{\mathrm{vi}}$ [1].

\section{The state of the law in Ontario}

Under Part XX.1, there are certain provisions to protect the liberty interests of accused persons found NCRMD or UST who remain under the authority of a provincial or territorial Board. When the Officer-inCharge ${ }^{\text {vii }}$ of the designated hospital (as defined under the Mental Health Act) significantly increases the restrictions on the liberty of the accused, these provisions are triggered [2].

\section{The 7-day trigger}

Section 672.56 speaks directly to restrictions on the liberty of the accused. Hospitals delegated by the Board can make decisions to increase or decrease the liberties of an accused person within the limits of the disposition. ${ }^{\text {viii }}$ This section also explicitly requires that the Officer-inCharge of the hospital make a record of 
the increased restrictions on the file of the accused and provide notice to the accused of the increase as soon as practicable. The Officer-in-Charge shall also give notice to the Board if the increased restrictions remain in place for a period exceeding seven days ${ }^{\mathrm{ix}}$ [1].

\section{Mandatory Review Hearing}

Section 672.81(2.1) requires the Board to hold a hearing to review a decision to significantly increase the restrictions on the liberty of the accused, as soon as practicable after receiving the notice from the Officer-in-Charge ${ }^{x}$ [3]. At the hearing, the witness for the Hospital (typically the attending psychiatrist), will explain why the decision was made to increase the restrictions on the liberty of the accused. The Board will then determine whether the actions of the Hospital were the least onerous and least restrictive in the circumstances $^{\mathrm{xi}}[4-6]$.

\section{Confinement under Provincial Legislation}

Confinement under provincial mental health legislation, such as the Mental Health Act $^{x i i}$ in Ontario, does not trigger these restriction review provisions. For example, if an individual residing in the community under a Conditional Discharge Disposition is readmitted to a forensic hospital under the authority of a Form 1 of the Mental Health Act ${ }^{\text {iii }}$, this would not constitute a significant increase on the restriction of the accused's liberties [2,7].

\section{The Campbell Decision}

The Ontario Court of Appeal released its decision in (Re) Campbe ${ }^{\text {xiv }}$ (Campbell) on February 14, 2018. In Campbell, the accused was found NCR in 2004 and had spent ten years at the Brockville Mental Health Centre before being transferred to the Royal Ottawa Hospital (the Royal) where she was ordered to be detained on a Secure Forensic Unit. Roughly six months into her detention at the Royal, Campbell began using illicit substances including alcohol, cocaine, and amphetamines. In an effort to curb her substance use, the Royal reduced her privilege levels and eventually moved her from one Secure Forensic Unit to a more Secure Forensic Unit [8].
The Royal notified the Board of the increase on the restrictions of Ms. Campbell's liberties two months after her transfer to a more secure unit. At the mandatory review hearing that followed under section 672.81(2.1), Ms. Campbell's counsel argued that the delay in notification resulted in a section 7 Charter breach and a section $24(1)$ remedy was due ${ }^{x v}[9,10]$.

The Central Issue and the Board's decision

The Board was divided on whether notice of a restriction of liberty was required, the majority concluded it was not, and therefore did not consider Ms. Campbell's Charter arguments. It concluded that the Royal's decision to move Ms. Campbell from one Secure Forensic Unit to another more Secure Forensic Unit was the least onerous and least restrictive measure in the circumstances. The Board emphasized that the transfer was a treatment decision, stemming from the Hospital's efforts to control Ms. Campbell's consumption of illicit substances which had an impact on her mental health and level of risk.

\section{Grounds for appeal}

The appellant raised four grounds for appeal, the primary of which focused on whether the Royal should have notified the Board of the change in Ms. Campbell's liberty status. For the purposes of this article, we will focus solely on the issue of notice to the Board. The parties asked for guidance from the Court of Appeal on this issue given that there is ambiguity in how to apply section 672.56(2). At the root of this issue is the test for identifying which restrictions on the liberty of the accused rise to the level of requiring notice to the Board $^{\mathrm{xvi}}[8]$.

\section{Ruling and Interpretation}

The appeal was dismissed. The Court of Appeal agreed with the Board's conclusion that the transfer was the least onerous and least restrictive measure in the circumstances. In its reasoning, the Court introduced new language to assist hospitals in determining when notice to the Board is required under section 672.56(2). The Court asked, "How significant is significantly?"xvii Weary of setting the bar too 
high (sacrificing the liberty interests of accused persons) or too low (creating unnecessary mandatory hearings and placing the Board in the position of secondguessing many of the hospital's decisions $)^{\text {xviil, }}$ the Court viewed section $672.56(2)$ as a contextual framework in which the Board has the role of safeguarding the liberty interests of accused persons [8].

\section{The "Liberty Norm"}

The Court was tasked with carefully delineating the approach hospitals must adopt in determining when notice to the Board is required. In its reasons, the Court explains that Hospitals must consider the liberty status of the accused before and after making decisions that increase restrictions on the liberty of the accused. At paragraph 65, the Court writes:

\begin{abstract}
"Calibrating the liberty norm requires consideration of the duration and pattern of liberty the NCR accused was experiencing before the decision or decisions resulting in increased restrictions on liberty. Determining the liberty norm does not ask what the individual may have been entitled to, but what he or she was actually experiencing before the increased restrictions were put in place. The liberty must be of sufficient duration to have become, objectively speaking, the NCR accused's norm" [emphasis added] ${ }^{\mathrm{xix}}$
\end{abstract}

This contextual approach requires that the hospital not only scrutinize the decision at the exact moment of increasing the restrictions on the liberties of the accused; it must also determine whether there was a pattern over time of restrictions resulting in a "whittling" of the accused's liberty interests. ${ }^{x x}$ The approach is carefully outlined at paragraph 66 of the Court's Reasons where it explains:

\footnotetext{
"The pre-existing liberty norm cannot always be determined by looking to the very moment before a decision is made that results in increases in restrictions on liberty. Decision by decision, an NCR accused's liberty interests may be whittled away over a period of time. While any one decision may not result in a significant increase in restrictions on liberty, all of the decisions combined may have this effect. Accordingly, when determining the NCR accused's liberty norm, hospitals should take a contextual approach, one that considers the individual's pattern of liberty in the recent past." $x \mathrm{xi}$
}

Once the liberty norm is determined, the hospital must compare it against the accused's liberty status following the in- creased restrictions. The change in liberty status must be reported to the Board where there is a clear deviation from the liberty norm. In its plainest iteration, the change in liberty status must not be trivial, but significant enough that a reasonable person, having knowledge of all of the circumstances, would think that the Board should be notified. The Court also opined that when the Hospital is in doubt, it should provide notice to the Board. ${ }^{x \mathrm{i}}$ In this case, the Court expressed that there was insufficient information regarding Ms. Campbell's liberty norm before and after the transfer to draw the conclusion that the restrictions rose to the level of requiring notice to the Board [8].

\section{Conclusion}

What does this mean for forensic hospitals moving forward? Hospitals should be aware of the new language introduced in Campbell and the contextual approach espoused by the Court of Appeal. There will be clear cases where notice of a restriction of liberties ought to be provided to the Board-for example, when an accused living in the community under a detention order is readmitted to hospital for a period exceeding seven days. However, there will inevitably be subtler cases. The contextual approach permits a broader interpretation of a restriction of liberty, opening up the potential for Charter litigation. Moving forward, hospitals must scrutinize their decisions to limit an accused's liberty interests by measuring the duration and pattern of liberty the accused was experiencing before the restrictions were imposed (liberty norm) and contrasting it with the liberty status resulting from the restrictions. Deviation from the liberty norm must be significant enough that a reasonable person would report it to the Board. When in doubt, hospitals should report the restriction to the Board. Although the interpretation of "significantly" increasing the restrictions on the liberties of the accused may have changed, the result remains much the same: the hospital bears the onus of proving that the restriction of liberty was the least onerous and least restrictive measure in the circumstances. Hospital staff should continue to document the 
circumstances leading up to the restriction and the reasoning behind their clinical decision to restrict the liberty interests of the accused and be prepared to defend that decision before the Board.

Conflict of interest: none

\section{References}

1. Criminal Code (Canada), R.S.C., 1985, c. C-46. (accessed on May 16, 2018)

2. Mental Health Act (Ontario), RSO 1990, c M.7 (accessed on May 16, 2018)

3. R. Saikaley, 2012 ONSC 6794. (accessed on May 16, 2018)

4. Not Criminally Responsible Reform Act, SC 2014 c-6. (accessed on May 16, 2018)

5. Osawe (Re), 2015 ONCA 280. (accessed on May 16, 2018)

6. Ranieri (Re), 2015 ONCA 444. (accessed on May 16, 2018)

7. Young 2011(Re) 2011 ONCA 432. (accessed on May 16, 2018)

8. Campbell (Re), 2018 ONCA 140. (accessed on May 16, 2018)

9. Canadian Charter of Rights and Freedoms, 1982, R.S.C. 1985. (accessed on May 16, 2018)

10. R. v. Conway, 2010 SCC 22, [2010] 1 S.C.R. 765. (accessed on May 16, 2018)

\section{Corresponding author:}

Lauren Barney, Forensic Psychiatry Program, St. Joseph's Healthcare Hamilton, Hamilton ON L9C 0E3, Canada - email: lbarney@stjosham.on.ca

Notes "Criminal Code, R.S.C., 1985, c. C-46, s. 672.38(1) [hereinafter "Criminal Code"]
ii Criminal Code, supra note 1, s.16 (1) "No person is criminally responsible for an act committed or an omission
made while suffering from a mental disorder that rendered the person incapable of appreciating the nature and
quality of the act or omission or of knowing that it was wrong."
iii Criminal Code, supra note 1, s. 2 "unfit to stand trial" means unable on account of mental disorder to conduct a
defence at any stage of the proceedings before a verdict is rendered or to instruct counsel to do so, and, in par-
ticular, unable on account of mental disorder to: (a) understand the nature or object of the proceedings, (b) under-
stand the possible consequences of the proceedings, or (c) communicate with counsel."

iv Criminal Code, supra note 1, s. 672.4(1)

v Criminal Code, supra note 1, s. 672.39; the Criminal Code requires that at least one member of the Review Board be entitled to practice psychiatry, and at least one member have experience in mental health and be entitled to practice psychology. In Ontario, the panel typically also has a lawyer and a public member.

vi Criminal Code, supra note 1, s. 672.72

vii Mental Health Act, RSO 1990, c M.7 [hereinafter "Mental Health Act"]; defines the Officer in Charge as the officer who is responsible for the administration and management of a psychiatric facility

viii Criminal Code, supra note 1, s. 672.56(1)

ix Criminal Code, supra note 1, s. 672.56

“ See: (Re) Saikaley, [2012] O.J. No. 572: "As soon as practicable" does not imply a set time-frame to hold a mandatory hearing under s. 672.81(2.1), rather it was the intent of Parliament "that the restriction hearing be set, held and concluded expeditiously." [para 68]

xi Not Criminally Responsible Reform Act, SC 2014 c-6. In July 2014, Part XX.1 of the Criminal Code was amended by parliament in Bill C-14, the Not Criminally Responsible Reform Act. Section s. 672.54 used to read "least onerous and least restrictive", this language was replaced by "necessary and appropriate" under Bill C-14. 
See also: Osawe (Re), 2015 ONCA 280, 125 O.R. (3d) 428, at para. 45; and Ranieri (Re), 2015 ONCA 444, 336 O.A.C. 88 , at paras. $19-21$.

xii Mental Health Act, supra note 7, see also: Centre for Addiction and Mental Health v. Young (2011), 273 C.C.C. (3d) 512

xiii Mental Health Act, supra note 7, Form 1, s. 15

xiv Campbell (Re), 2018 ONCA 140 [hereinafter "Campbell”]

${ }^{x v}$ Canadian Charter of Rights and Freedoms, 1982, R.S.C. 1985, App. II, No. 44, Schedule B, s. 7, s.24(1); In R. v. Conway, 2010 SCC 22, [2010] 1 S.C.R. 765, the Supreme Court of Canada ruled that Review Boards, as specialized tribunals created under the Criminal Code, have the jurisdiction to decide Charter issues.

xvi Campbell, supra, note 14 at para 5-6

xvii Campbell, supra note 14 at para 62

xviii Campbell, supra note 14 at para 62-63

xix Campbell, supra note 14 at para 65, [emphasis added]

${ }^{x x}$ Campbell, supra note 14 at para 66

xxi Ibid

xxii Campbell, supra note 14 at para 69 